\title{
RESEARCH
}

Open Access

\section{Ecological implications of twentieth century reforestation programs for the urban forests of São Paulo, Brazil: a study based on litterfall and nutrient cycling}

Maurício Lamano Ferreira ${ }^{1,2^{*}}$ (D), Marcelo Ferreira Barbosa ${ }^{3}$, Eduardo Pereira Cabral Gomes ${ }^{4}$, Ana Paula Branco do Nascimento ${ }^{5}$, Edgar Fernando de Luca ${ }^{6}$, Karina Gonçalves da Silva ${ }^{7}$, Ulisses Bezerra França ${ }^{8}$, Plínio Barbosa de Camargo ${ }^{7}$ and Raffaele Lafortezza ${ }^{9,10}$

\begin{abstract}
The focus of this study was to investigate the wide use of Eucalyptus spp., an exotic plant with high allelopathic ability, in the reforestation programs of urban parks in São Paulo City, Brazil, over the last century. To understand the implications of using Eucalyptus spp. in the city's parks, this study aimed to compare nutrient cycling and litter decomposition between a mixed composition of litter (i.e., native and exotic species) and the litter of a single species (i.e., Eucalyptus). To accomplish this, newly deciduous leaves were collected from two native and two exotic species that are commonly used in the afforestation of São Paulo as well as from Eucalyptus spp. The mixed composition of litter yielded a higher dry mass loss and return of macro- and micronutrients to the forest floor. The decomposition constant $\left(k\right.$ ) values were 0.00322 and $0.00207 \mathrm{~g} \mathrm{~g}^{-1}$ day ${ }^{-1}$ for the mixed composition and Eucalyptus spp., respectively. The time required for decomposition of 50 and $95 \%$ of deciduous material was 215 and 931 days, respectively, and for the mixed litterfall 334 and 1449 days, respectively, for Eucalyptus spp. Therefore, the mixed litter exhibited greater dry mass loss and nutrient cycling in an urban forest of São Paulo City, since dry mass losses as well as speed and amount of nutrients returned to the forest floor were relatively higher compared to Eucalyptus spp. Nutrient cycling via Eucalyptus spp. litter was less efficient than mixed composition of litter, demonstrating that reforestation programs carried out in the twentieth century using only one species may have had little success. The results of this work emphasize the fact that in urban reforestation programs the City of São Paulo must consider the environmental and biogeographic characteristics of the species employed and use high levels of biodiversity, since the city lies in a megadiverse biome.
\end{abstract}

Keywords: Tropical forest, Exotic species, Nutrient dynamics, Ecosystem functioning

\footnotetext{
* Correspondence: mauecologia@yahoo.com.br

${ }^{1}$ Master's Program in Health Promotion, Adventist University of São Paulo,

São Paulo, SP, Brazil

${ }^{2}$ Master's Program in Geoenvironmental Analysis, University of Guarulhos,

Guarulhos, SP, Brazil

Full list of author information is available at the end of the article
}

\section{Springer Open}

๑) The Author(s). 2021 Open Access This article is licensed under a Creative Commons Attribution 4.0 International License, which permits use, sharing, adaptation, distribution and reproduction in any medium or format, as long as you give appropriate credit to the original author(s) and the source, provide a link to the Creative Commons licence, and indicate if changes were made. The images or other third party material in this article are included in the article's Creative Commons licence, unless indicated otherwise in a credit line to the material. If material is not included in the article's Creative Commons licence and your intended use is not permitted by statutory regulation or exceeds the permitted use, you will need to obtain permission directly from the copyright holder. To view a copy of this licence, visit http://creativecommons.org/licenses/by/4.0/. 


\section{Introduction}

The unprecedented expansion of urban centers in Brazil during the twentieth century has led to the insurgence of several environmental hazards such as soil, water, and air pollution (Ferreira et al. 2012; Pedroso et al. 2016; Nakazato et al. 2020), which are the consequence of an inadequately balanced management of urban green spaces (Chen and Hua 2015; Benchimol et al. 2017). Recently, these environmental concerns have received greater attention in terms of public policy, and topics such as biodiversity and environmental conservation have become an important focus in Brazilian (urban) society (Adams 2005; Botelho et al. 2014; Ferreira et al. 2018; Bulbovas et al. 2020).

Historically, public management in some Brazilian cities, including São Paulo, has mainly focused on industrial development resulting in restoration programs not receiving proper solicitude during the last century. As a consequence, the introduction of fast-growing exotic tree species offering shade has become the typical practice in urban centers (Jesus et al. 2014; Silva et al. 2016). However, this strategy has resulted in the expansion of exotic and alien species attracting pollinators (Hoppen et al. 2015), thus contributing to biotic homogenization in cities (Lôbo et al. 2011; Qian et al. 2016).

São Paulo's urban green spaces are mainly composed of exotic plants with high ornamental potential, such as Ligustrum lucidum and Ficus benjamina. These trees, along with many other native species, such as Schinus terebinthifolius and Pleroma granulosum, are scattered throughout the city providing important ecosystem services (Lafortezza and Chen 2016; Arratia et al. 2020). Exotic trees, such as Eucalyptus spp., are excellent competitors in the natural system because of allelopathy and their ability to alter floristic composition and soil properties (Suominien 2013; Yitaferu et al. 2013; Gatto et al. 2014; Sampaio and Schmidt 2014; Silva et al. 2016; Shams 2016; Stromberg et al. 2016). Some studies have shown that the decomposition rate of Eucalyptus leaves is slower than that of native species (Louzada et al. 1997; Barlow et al. 2007; Bala et al. 2010; Demessie et al. 2012; Martins et al. 2013; Cizungu et al. 2014). However, several other cases have shown a faster decomposition rate (Pozo et al. 1998; Ferreira et al. 2006; Bachega et al. 2016) or absence of differences (Guo and Sims 1999; Costa et al. 2005) in various parts of Brazil. In general, species-specific effects, which are considerable, are more capable of determining the variations in decomposition rates than whether or not a species is autochthonous (Kumar 2008). The Eucalyptus spp. most commonly planted in the urban parks of São Paulo is Eucalyptus grandis; it is sometimes hybridized with E. urophylla. The species and its hybrids are fast growing, reaching more than $50 \mathrm{~m}$ in height in a few decades. They have been widely used from the early to mid-twentieth century as a means of "draining" humid soil. Due to certain characteristics of the species, such as an abundance of oil in the leaves and leaf laminae, the decomposition rate is expected to be slower than that of most native species in the study region.

Although litter decomposition and nutrient cycling are important ecosystem processes (Ferreira et al., 2017; Sousa-Neto et al. 2017), little is known about them in the tropical and subtropical urban forests of the southern hemisphere (Silva-Junior et al. 2014; Enloe et al. 2015; Ferreira et al. 2019). Some authors have shown and compared litterfall production and decomposition rates in tropical urban systems and natural areas; however, research of this nature is still little explored in Brazil (Ferreira et al. 2014a; Ferreira et al. 2014b; Martinelli et al. 2017). In this context, the processes of underlying forest dynamics in public spaces must be investigated with the aim of improving biodiversity management in green urban areas. In this study, it can be inferred that the urban area influences litterfall decomposition processes, especially since it interferes with microbial activities, i.e., external factors such as microclimate and deposition of atmospheric contaminants that can vary considerably in less anthropized areas (Moraes et al. 1999). Therefore, this study is driven by the hypotheses that (i) the decomposition of Eucalyptus leaves will be slower than the decomposition of mixed-leaf ornamental species (i.e., two other exotic plus two native species), as is traditionally found in São Paulo's treescape, and (ii) the rates of return to the soil of nutrients from canopy leaves and litterfall of Eucalyptus will be slower than those from the mixed composition over time. To test these hypotheses, we evaluated the rate of litter decomposition and return of nutrients between Eucalyptus leaves and a mixed composition of exotic and native leaves over a period of 6 months to determine the implications of using Eucalyptus spp. as an alternative for treescape replacement. The results of this investigation will be of great importance in promoting public policies that have been prepared by the City of São Paulo, such as the Municipal Plan for Urban Afforestation, and the Municipal Plan for Protected Areas, Green Areas, and Free Spaces, among others.

\section{Materials and methods Study area}

The region comprising the study area of São Paulo is characterized by a warm, temperate climate with variable rainfall throughout the year (Fig. 1). The average temperature is approximately $18.5{ }^{\circ} \mathrm{C}$, and the yearly pluviometric precipitation is about $1340 \mathrm{~mm}$. The driest month of the year is July, while the wettest is January. February is the hottest month of the year, with an 


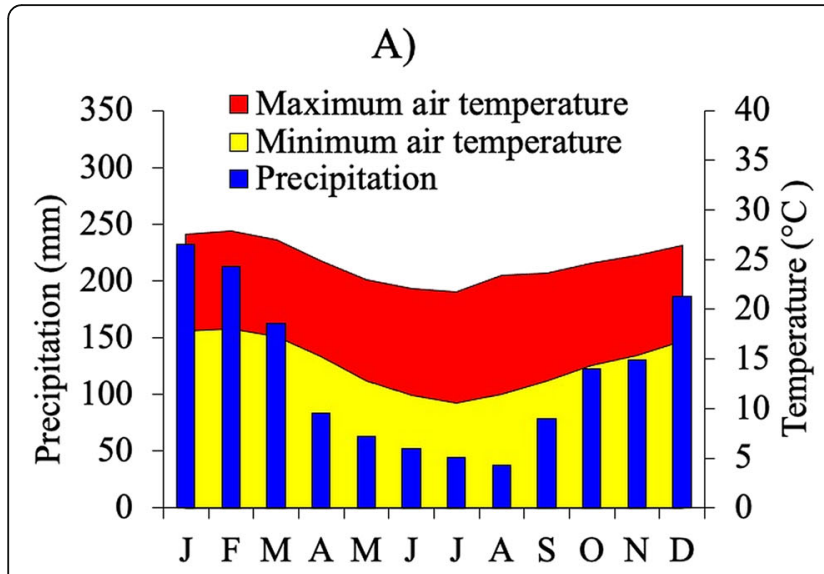

B)

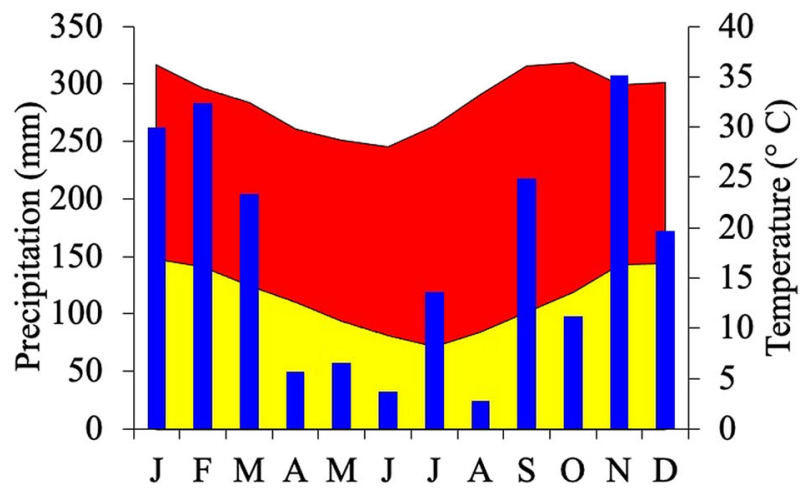

Fig. 1 a Historical series (1933-2014) for average accumulated pluviometric precipitation values, and maximum and minimum air temperatures for the City of São Paulo, Brazil. b Values for the same abiotic variables during the 2015 period of study (IAG-USP 2015)

average air temperature of $21.3{ }^{\circ} \mathrm{C}$ (Climate-Data.Org 2015. According to the Brazilian Institute of Geography and Statistics, the city of São Paulo counts approximately 12.5 million inhabitants and has a population density of 7.4 inhabitants $/ \mathrm{km}^{2}$ (IBGE 2020). Hence, the metropolitan area of São Paulo (MASP) produces a significant urban heat island effect. The center of the MASP is significantly warmer than its surroundings (i.e., green belt zone around MASP), having reached an increase in temperature of $3.8{ }^{\circ} \mathrm{C}$ over the past 80 years. The warmer built-up area also has lower relative humidity, greater thermal variability, and more intense and concentrated rainfall (IAG/USP 2015; Lima and Rueda 2018).

The study was carried out in Jardim Conquista Park, located in eastern São Paulo, which extends over an area of $559,292 \mathrm{~m}^{2}$. This site was preserved as a protected area in 2014, but till now, no studies on floristic composition and vegetation structure have been reported. Nevertheless, it is possible to identify the presence of exotic species, for example, L. lucidum and Eucalyptus spp., among several other native species such as $P$. granulosum and $S$. terebinthifolius. The physicalchemical characteristics of the soil classify the study area as dystrophic yellowish-red latosol, typical, medium texture, with minimum content between 15 and 35\%, and slightly acid pH (Table 1) (MDA 2008).

Table 1 Chemical properties of the soil in Parque Jardim da Conquista, the site of litterfall material exposure. $\mathrm{pH}$ potential of hydrogen, $P$ phosphorus $\left(\mathrm{mg} / \mathrm{dm}^{3}\right), K$ potassium $\left(\mathrm{mg} / \mathrm{dm}^{3}\right), \mathrm{Ca}$ calcium $\left(\mathrm{cmolc} / \mathrm{dm}^{3}\right), M g$ magnesium $\left(\mathrm{cmolc} / \mathrm{dm}^{3}\right), H+A l$ hydrogen + aluminum $\left(\mathrm{cmolc}^{\left.\mathrm{d} \mathrm{dm}^{3}\right)}\right.$, SB sum of bases ( $\mathrm{cmolc}$ ) $\left.\mathrm{dm}^{3}\right)$, SOM soil organic matter (dag/kg), $V$ base saturation (\%)

\begin{tabular}{llllllllll}
\hline Soil depth & $\mathbf{p H}$ & $\mathbf{P}$ & $\mathbf{K}$ & $\mathbf{C a}$ & $\mathbf{M g}$ & $\mathbf{H}+\mathbf{A l}$ & $\mathbf{S B}$ & SOM & $\mathbf{V}$ \\
\hline $0-20 \mathrm{~cm}$ & 6.1 & 230 & 207 & 5.35 & 1.72 & 1.9 & 7.6 & 2.74 & 80 \\
\hline
\end{tabular}

\section{Litter decomposition}

Litter decomposition was assessed in terms of dry mass loss over time. In the first step of the assessment procedure, the leaves of native and exotic trees (Table 2) were randomly collected in litter traps and dried in an oven at $65{ }^{\circ} \mathrm{C}$ for 7 days. Afterwards, 72 nylon bags with a $1-\mathrm{mm}$ opening (litterbags), measuring $25 \mathrm{~cm} \times 25 \mathrm{~cm}$, were filled with $10 \mathrm{~g}$ of the dry leaves. In the second step, 36 litterbags were prepared with a mixed composition of leaves from two native and two exotic species (hereinafter termed "mixed litterfall fraction" or MLF), and other 36 litterbags were prepared solely with the leaves of Eucalyptus spp. (hereinafter termed Eucalyptus spp. fraction or "EU") (Table 2).

All the litterbags were randomly spread out on the soil of Jardim Conquista Park. For litter dry mass loss and nutrient return assessment, 12 litterbags were removed each month from the study area over a period of 6 months (Ferreira et al. 2014b). In the laboratory, the contents of each bag were washed under running water for $5 \mathrm{~min}$ to remove any excess nutrients from the leaves, whether originating from the park's fauna or from atmospheric deposition, and dried in an oven at 65 ${ }^{\circ} \mathrm{C}$ for 7 more days.

According to the method of Ferreira et al. (2014b) and Ferreira and Uchiyama (2015), the litter decomposition rate was estimated applying an exponential model (Thomas and Asakawa 1993). The decomposition constant $k$, half-life $\left(t_{0.5}\right)$, and loss of $95 \%\left(t_{0.05}\right)$ of the material were estimated based on the calculations of Shanks and Olson (1961).

\section{Macro- and micronutrient cycling}

To conduct a nutritional analysis of the leaves in canopy, about 15 mature and expanded leaves were collected from the extremities of branches given the fact that nutrient distribution increases or decreases in relation to 
Table 2 Taxonomic and biogeographic characteristics of the chosen species in the present study

\begin{tabular}{lllll}
\hline Species & Family & Popular name & Geographic origin & Status \\
\hline Eucalyptus spp. & Myrtaceae & Eucalyptus & Australia & Japan \\
Ligustrum lucidum & Oleaceae & Japanese privet & Asia & Exotic \\
Ficus benjamina & Moraceae & Fig tree & Brazil & Native \\
Schinus terebinthifolius & Anarcadiaceae & Brazilian peppertree & Brazil & Native \\
Tibouchina granulosa & Melastomataceae & Purple glory tree & & \\
\hline
\end{tabular}

the position of the leaf in the canopy (Magalhães and Blum 1999). Subsequently, all the leaves were dried in an oven at $65{ }^{\circ} \mathrm{C}$ for 7 days. The leaf material was then separated into 12 bags, 6 with MLF and 6 with EU leaves alone. All the material was chemically analyzed to determine nutrient contents. Carbon was estimated as $45 \%$ of the dry mass of the leaves (Lewis et al. 2009; Saatchi et al. 2011). The nutritional analysis of the leaves was carried out according to the method of Martins and Reissmann (2007). To analyze nitrogen translocation efficiency (NTE), the model proposed by Finzi et al. (2001) was applied as follows:

$$
\mathrm{NTE} \%=\frac{(N \text { in green leaves })-(N \text { in litterfall leaves })}{(N \text { in green leaves })}
$$

\section{Data analyses}

Loss of nutrients and dry mass over time was assessed using regression models. Several authors have reported high $R^{2}$ values $(>70 \%)$ for litter decomposition through time in the tropics (Ferreira et al. 2014a; Ferreira et al. 2014b; Giweta 2020). To identify homogeneous groups based on litter origin (MLF or Eucalyptus spp.), a nonmetric multidimensional scaling (NMDS) analysis was performed. The Bray-Curtis similarity metric index was employed in this analysis, considering a stress value < 0.15 . Dissimilarity between the groups was tested using a multivariate analysis of similarity (one-way analysis of similarities, ANOSIM), considering a Bonferronicorrection $p$ value of $\leq 0.05$ and $R$ value of $<1$ as significant. Multivariate analysis of variance (MANOVA) was used to determine if variance in the concentration of nutrients in the litter showed significant differences between the two types of material (MLF or EU). Concentration of nutrients was considered a dependent variable in the model, and the origin of the material (MLF or EU) was considered as an independent variable.

For metric standardization, all variances were standardized using $z$-transformation. The analyses were performed with SPSS Statistics 20 (Armonk, NY: IBM Corp).

\section{Results}

\section{Litter decomposition}

The material formed by MLF lost more mass over time than the material formed by EU. The decomposition constant $(k)$ for MLF was estimated as $0.00322 \mathrm{~g} \mathrm{~g}^{-1}$ day $^{-1}$ and for EU as $0.00207 \mathrm{~g} \mathrm{~g}^{-1}$ day $^{-1}$, with $t_{0.5}=215$ and $t_{0.05}=931$ days for MLF, and $t_{0.5}=334$ and $t_{0.05}=$ 1449 days for EU. The rate of dry mass loss over time was faster in the bags with MLF compared to those with EU material (Fig. 2). In general, the beginning of the MLF decomposition curve was more pronounced, while in both cases a greater mass loss was observed in the first 30 days. After this time, the remaining dry mass values stabilized. $R^{2}$ values show that the model was highly reliable for the exponential decomposition presented by Shanks and Olson (1961), since it explained $84 \%$ of MLF decomposition and $90 \%$ of EU decomposition. The decomposition constant found is in the range of other studies in tropical forest (Table 3).

\section{Macro- and micronutrient return}

The average nutritional values found in canopy leaves which formed MLF differed from the values found for EU leaves. Overall, the fallen leaves of Eucalyptus contained a lower quantity of macronutrients. For example, the average nitrogen $(\mathrm{N})$ and potassium $(\mathrm{K})$ values were slightly lower in EU tree leaves than in the mixed leaves of the other trees (i.e., MLF). A similar trend was observed for other nutrients, such as calcium (Ca) and zinc ( $\mathrm{Zn})$, which presented

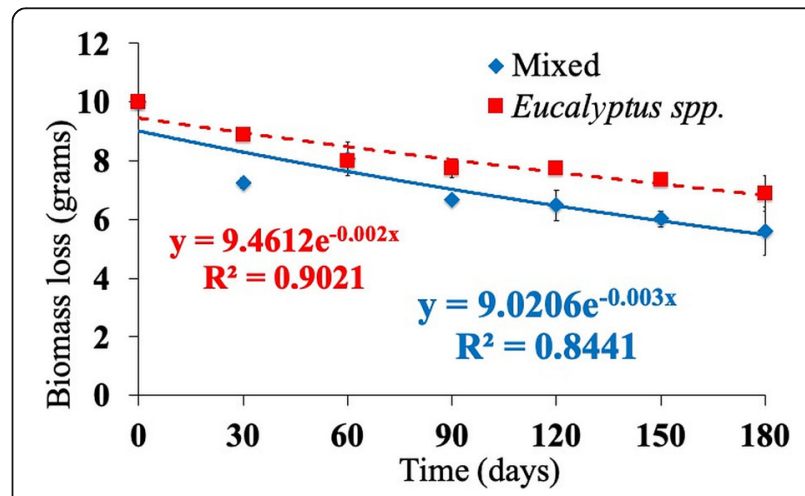

Fig. 2 Biomass loss over time for mixed species (diamonds with blue line) and Eucalyptus spp. (red squares with dotted line) litter 
Table 3 Decomposition constant $(k)$ and time required for decomposition of 50\% and 95\% of litter in studies conducted in the Atlantic Forest and Cerrado biomes. $t_{0.5}$ and $t_{0.05}$ time required to decompose $50 \%$ and $95 \%$ of the litter, respectively; BI biome (AF Atlantic Forest, CE Cerrado); PR precipitation

\begin{tabular}{lllllll}
\hline Location & BI & PR $(\mathbf{m m})$ & $\boldsymbol{k}$ & $\boldsymbol{t}_{\mathbf{0 . 5}}$ & $\boldsymbol{t}_{\mathbf{0 . 0 5}}$ & Source \\
\hline São Paulo, SP, Brazil & AF & 1300 & 0.0027 & 248 & 1069 & (Ferreira et al. 2014a, 2014b) \\
Itaguaí, RJ, Brazil & AF & 2097 & 0.0049 & 124 & 540.2 & Valente et al. (2005) \\
São Paulo, SP (mixed litter) & AF & 1300 & 0.0032 & 215 & 931 & This work \\
São Paulo, SP (Eucalyptus spp.) & AF & 1300 & 0.0020 & 334 & 1449 & This work \\
Guaraqueçaba, PR, Brazil & AF & 2000 & 0.0068 & 365 & 1606 & Scheer (2008) \\
Luis Antônio, SP, Brazil & CE & 1684 & 0.0056 & 657 & 839.5 & Cianciaruso et al. (2006) \\
\hline
\end{tabular}

concentrations three and two times lower in the EU group compared to the MLF group, respectively. However, it is worth noting that the manganese (Mn) concentration was much higher in the canopy leaves of Eucalyptus. When comparing the nutritional state of leaves in canopy with those recently fallen, we observed a loss of about $24 \%$ of N, $51 \%$ of phosphorus (P), $3.7 \%$ of $\mathrm{K}$, and $14 \%$ of boron (B) for the MLF composition after leaf fall. EU leaves showed a loss of approximately $22 \% \mathrm{~N}, 52 \% \mathrm{P}, 33 \% \mathrm{~K}$, and $20 \% \mathrm{~B}$. In this species, the concentration of $\mathrm{Mn}$ in canopy leaves was $31 \%$ higher than in that of fallen leaves (Table 4).

NTE was very similar in both leaf materials, with values of $22.93 \%$ for MLF and $24.03 \%$ for EU. In general, the macro- and micronutrient values found in MLF were higher than those found in EU, demonstrating that $\mathrm{Eu}$ calyptus leaves are nutritionally poorer. Each macronutrient returned to the soil at different rates over time. Nitrogen, for example, showed a similar curve between MLF and EU, with values and inclinations almost overlapping (Fig. 3a). In contrast with $\mathrm{N}$, the values and

Table 4 Nutritional values of leaves in the canopy and litter. $N$ nitrogen $\left(\mathrm{g} \mathrm{kg}^{-1}\right), P$ phosphorus $\left(\mathrm{g} \mathrm{kg}^{-1}\right), K$ potassium $\left(\mathrm{g} \mathrm{kg}^{-1}\right), \mathrm{Ca}$ calcium ( $\left(\mathrm{g} \mathrm{kg}^{-1}\right)$, Mg magnesium $\left(\mathrm{g} \mathrm{kg}^{-1}\right), S$ sulfur $\left(\mathrm{g} \mathrm{kg}^{-1}\right), B$ boron $\left(\mathrm{mg} \mathrm{kg}^{-1}\right)$, Zn zinc $\left(\mathrm{mg} \mathrm{kg}^{-1}\right), \mathrm{Mn}$ manganese $\left(\mathrm{mg} \mathrm{kg}^{-1}\right)$, Fe iron ( $\left.\mathrm{mg} \mathrm{kg}^{-1}\right)$, Cu copper ( $\mathrm{mg} \mathrm{kg}^{-1}$ )

\begin{tabular}{llllll}
\hline Nutrients & Canopy & & \multicolumn{2}{l}{ Litter } \\
\cline { 2 - 3 } \cline { 5 - 5 } \cline { 5 - 5 } & Mixed & Eucalyptus spp. & Mixed & Eucalyptus spp. \\
\hline $\mathrm{N}$ & $12.9 \pm 0.11$ & $11.6 \pm 0.65$ & $9.80 \pm 0.70$ & $8.94 \pm 0.70$ \\
$\mathrm{P}$ & $1.36 \pm 0.13$ & $0.72 \pm 0.04$ & $0.66 \pm 0.09$ & $0.34 \pm 0.11$ \\
$\mathrm{~K}$ & $10.6 \pm 0.95$ & $7.82 \pm 0.16$ & & $10.2 \pm 0.88$ & $5.26 \pm 0.67$ \\
$\mathrm{Ca}$ & $28.1 \pm 2.21$ & $15.1 \pm 1.26$ & $41.4 \pm 3.24$ & $13.2 \pm 1.82$ \\
$\mathrm{Mg}$ & $3.66 \pm 0.42$ & $2.16 \pm 0.11$ & $3.22 \pm 0.31$ & $1.60 \pm 0.23$ \\
$\mathrm{~S}$ & $2.92 \pm 0.18$ & $0.98 \pm 0.04$ & $3.06 \pm 0.15$ & $0.64 \pm 0.05$ \\
$\mathrm{~B}$ & $24.1 \pm 1.43$ & $23.5 \pm 1.33$ & $20.7 \pm 0.95$ & $18.7 \pm 1.68$ \\
$\mathrm{Zn}$ & $86.8 \pm 24.6$ & $22.5 \pm 2.04$ & $70.4 \pm 18.8$ & $22.4 \pm 1.39$ \\
$\mathrm{Mn}$ & $98.4 \pm 21.1$ & $1022.0 \pm 69.1$ & $77.7 \pm 19.8$ & $700.8 \pm 81.3$ \\
$\mathrm{Fe}$ & $115.1 \pm 14.0$ & $145.4 \pm 41.5$ & $113.6 \pm 10.1$ & $102.3 \pm 11.8$ \\
$\mathrm{Cu}$ & $5.84 \pm 0.56$ & $7.62 \pm 0.70$ & $4.10 \pm 0.49$ & $4.46 \pm 0.33$ \\
\hline
\end{tabular}

inclinations of phosphorus, calcium, and magnesium were originally greater in MLF compared to EU, but over time, nutrient loss basically occurred at the same speed in both MLF and EU given that the slopes of the curves were similar (Fig. 3 b, d, and e). The litter composition of MLF and EU released elevated amounts of K into the soil in the first month of exposure and then stabilized over time (Fig. 3c). The sulfur contained in MLF litterfall declined in the first months of exposure, while EU litter maintained its low level of release from start to finish of exposure (Fig. 3f).

For micronutrients, B presented similar curves for both MLF and EU litterfall, with a greater reduction in soil nutrient return after the third month of exposure (Fig. 4a). The initial concentration of $\mathrm{Zn}$ in MLF was about 3-fold higher than that of EU and remained higher throughout the observation period (Fig. 4b). Manganese was the only nutrient that showed a slightly steep curve for both types of litterfall. The initial amount of $\mathrm{Mn}$ in the Eucalyptus litterfall was nearly three-fold higher than the amount found in the mixed litterfall (Fig. 4c). Iron (Fe) concentration in MLF showed strong variability of data around the average for most observed values. This element showed a decomposition curve oscillating over time with absolute values at the beginning of exposure twice those for MLF at the end of the study (Fig. 4d). Both types of litterfall presented very similar curves for copper $(\mathrm{Cu})$ loss, and a gradual loss could be observed by the end of leaf exposure (Fig. 4e).

In relative terms, dry mass loss in the MLF material was observed to be higher than that in the EU material, with values of about $44 \%$ and $31 \%$, respectively (Table 5). Overall, MLF macronutrients demonstrated relative losses which were more dramatic when compared to the EU material, except for $\mathrm{P}$ and $\mathrm{Ca}$. The micronutrients also presented the same trend, except for $\mathrm{Zn}$.

The MLF material, in general, had lower carbon $\mathrm{C} / \mathrm{N}$, $\mathrm{C} / \mathrm{P}$, and $\mathrm{N} / \mathrm{P}$ ratios than the $\mathrm{EU}$ material, and from the fourth month of exposure, the $\mathrm{C} / \mathrm{N}$ ratio, as well as the $\mathrm{C} / \mathrm{P}$ ratio, registered a greater increase. The N/P ratio showed a decreasing curve over time (Fig. 5). 

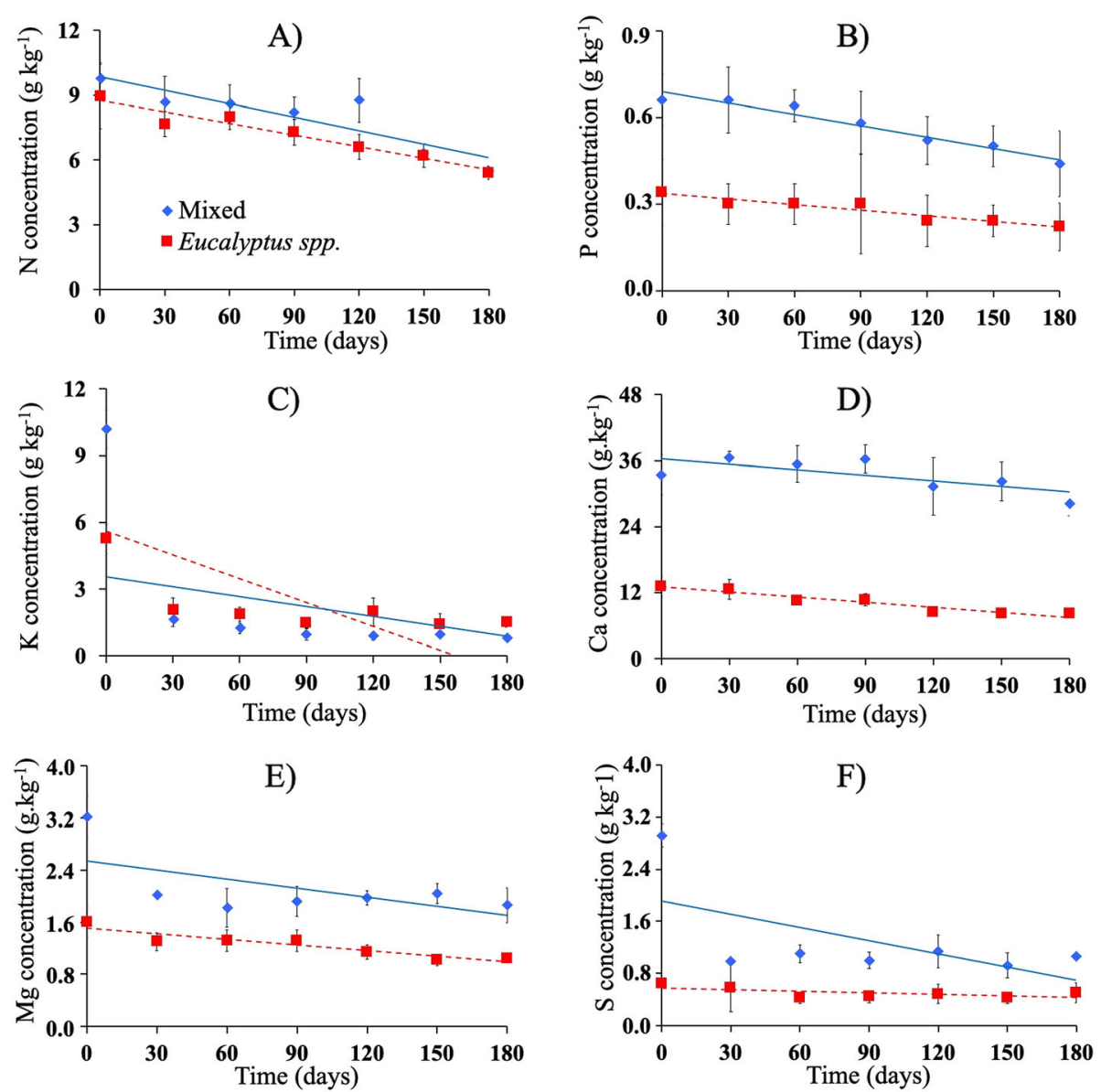

Fig. 3 Loss of macronutrients over time in mixed species (diamonds with blue lines) and Eucalyptus spp. (red squares with dotted lines). a Nitrogen loss, b phosphorus loss, $\mathbf{c}$ potassium loss, $\mathbf{d}$ calcium loss, e magnesium loss, $\mathbf{f}$ sulfur loss

\section{Comparing mixed and Eucalyptus compositions}

After performing multivariate analyses, the loss of macro- and micronutrients showed two homogeneous groups promoting a distinct separation of the material composed by MLF and Eucalyptus spp. alone (Fig. 6). Thus, the lack of clustering between the groups shows the high dissimilarity between the MLF and EU compositions. Moreover, the EU sample group presented a greater internal similarity, which was to be expected since the group formed by the mixed composition presented higher diversity due to the combination of exotic and native species. The separation into homogeneous groups, as shown by NMDS, was significant with statistical inference values of $p<0.0001$ and $R=0.75$, as determined by ANOSIM. This means that for the analyzed variables (macro- and micronutrients), the set of EU leaves presented different characteristics of nutrient cycling when compared to MLF.

MANOVA showed a multivariate difference in the effect of litter origin, unlikely to have occurred by sample mistake or by accident, presenting a $p$ value of
$>0.001$ (Table 6). It is also possible to observe that this effect in litter origin is responsible for about $98 \%$ of multivariate variability in the dataset $\left(\eta^{2}\right.$ partial $\left.=0.979\right)$, corroborating the NMDS graphics.

\section{Discussion}

This study revealed that the decomposition constant $(k)$ and time to decompose 50 and $95 \%$ of litter was close to the expected for non-urban rainforests. The values reported by Ferreira et al. (2014b), who also conducted a similar study in the urban area of São Paulo, were close to those found for the mixed litter in this study. On the other hand, the $k$ values presented by Valente et al. (2005), who studied a location with similar vegetation type, were almost half those observed in our study. In this case, it can be inferred that urban areas influence litter decomposition processes, especially because they interfere with microbial activities, i.e., external factors such as microclimate and the deposition of atmospheric contaminants that can vary considerably in less anthropized areas (Moraes et al. 1999). Several other factors 


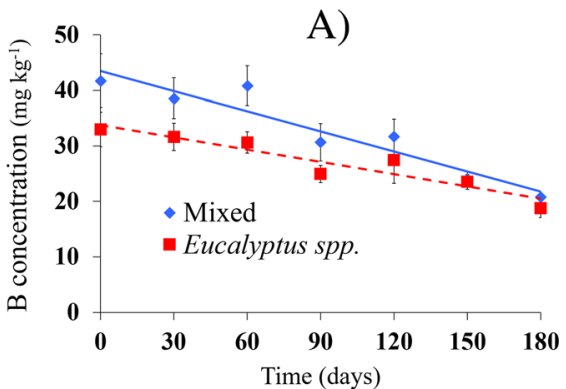

C)
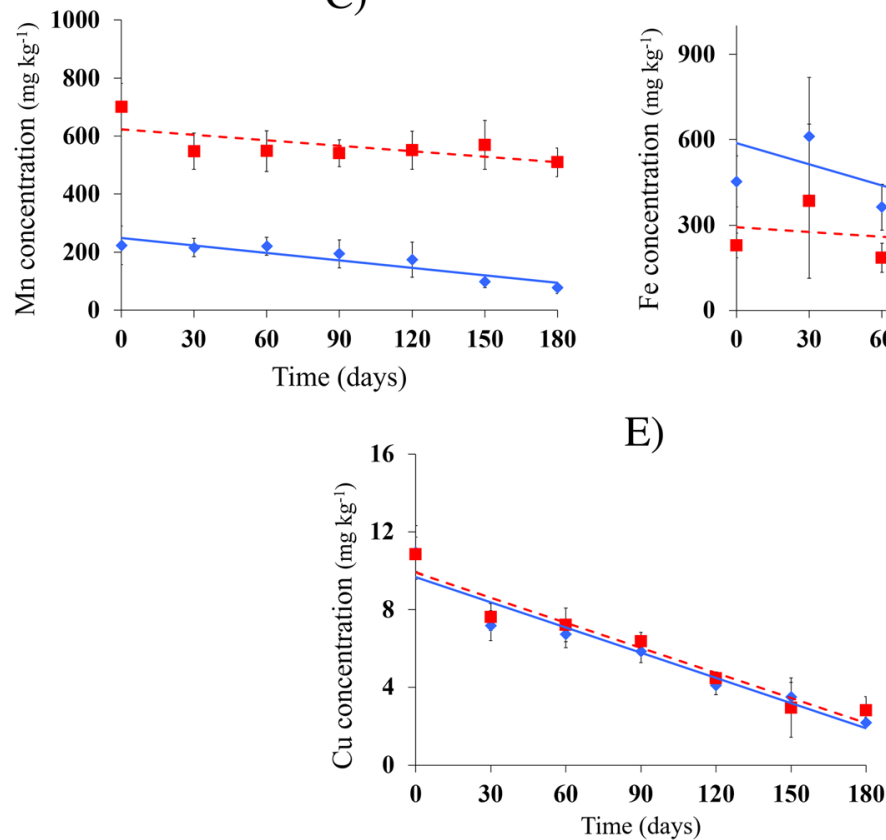

Fig. 4 Loss of micronutrients over time in mixed species (diamonds with blue lines) and Eucalyptus spp. (red squares with dotted lines). a Boron loss, b zinc loss, c manganese loss, $\mathbf{d}$ iron loss, e copper loss

might interfere with decomposition processes. Scheer (2008) reported that abiotic factors have a strong influence on litter decomposition rates, especially in the first months of exposure when high values of available macronutrients are found in deciduous material (Fig. 3). This finding lends support to the evidence that divergent particularities can affect nutrient return to urban forest soil.

Of relevance is the fact that the edaphic flora and soil macro-invertebrates responsible for litter degradation and decomposition might differ in urban areas as a result of insufficient space to maintain stable populations, which, in turn, may be reflected in the time required to decompose organic material. However, considering that the MLF and EU material were under the same climatic regime and environmental interferences, Eucalyptus litter was less efficient in losing mass to the forest floor than that formed by MLF. Thus, the results confirm the hypothesis that the leaves of MLF material are, in fact,

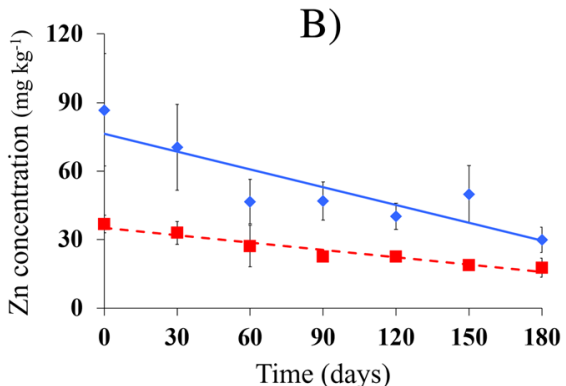

D)

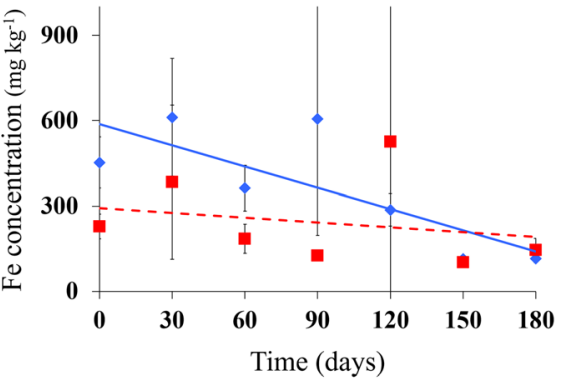

E) Eucalyptus spp. litter between the first and last month of observation. N nitrogen, $P$ phosphorus, K potassium, Ca calcium, Mg magnesium, $S$ sulfur, B boron, $\mathrm{Zn}$ zinc, $\mathrm{Mn}$ manganese, $\mathrm{Fe}$ iron, Cu copper

\begin{tabular}{lll}
\hline Nutrient/mass & Mixed (\%) & Eucalyptus spp. (\%) \\
\hline Mass & 44.0 & 31.1 \\
$\mathrm{~N}$ & 43.9 & 39.6 \\
$\mathrm{P}$ & 24.2 & 35.3 \\
$\mathrm{~K}$ & 92.4 & 71.5 \\
$\mathrm{Ca}$ & 19.5 & 24.6 \\
$\mathrm{Mg}$ & 42.2 & 35.0 \\
$\mathrm{~S}$ & 65.4 & 21.9 \\
$\mathrm{~B}$ & 46.2 & 45.7 \\
$\mathrm{Zn}$ & 28.2 & 39.0 \\
$\mathrm{Mn}$ & 60.2 & 27.3 \\
$\mathrm{Fe}$ & 78.7 & 66.5 \\
$\mathrm{Cu}$ & 64.2 & 59.3 \\
\hline
\end{tabular}



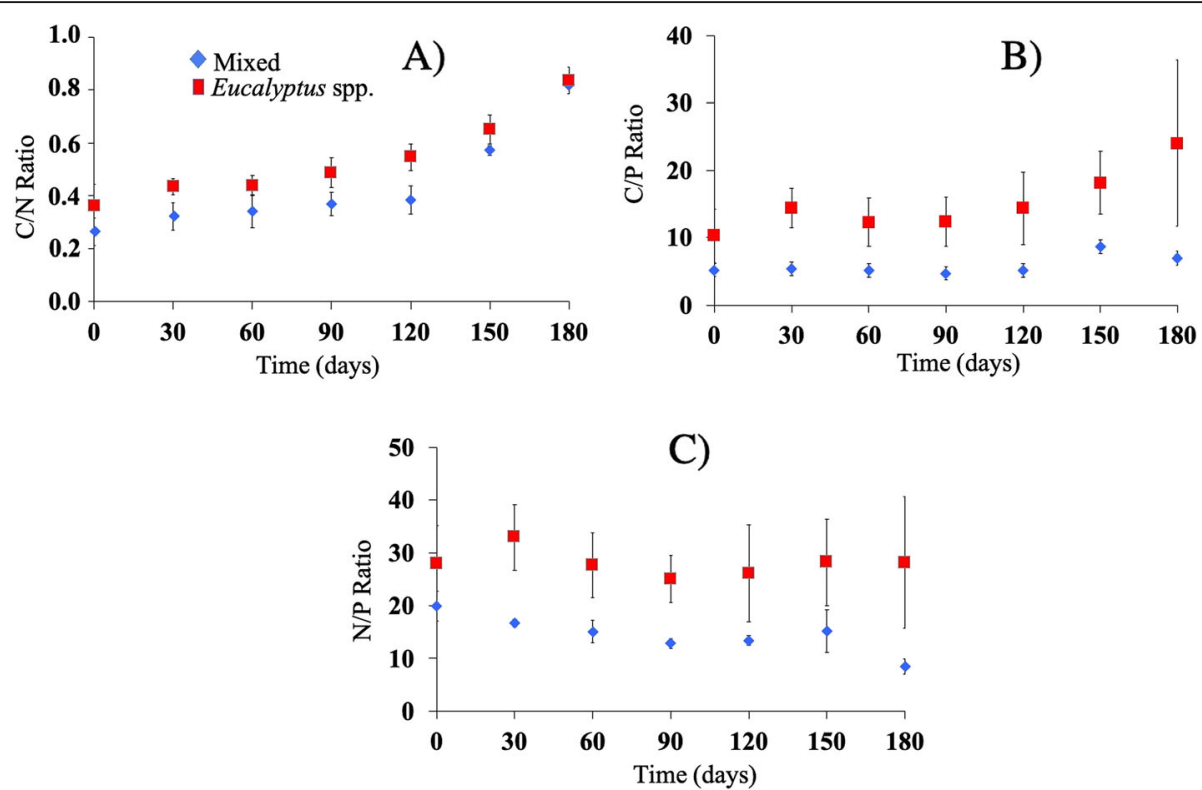

Fig. 5 Nutrient ratios of mixed and Eucalyptus spp. litter. a The C/N ratio, b C/P ratio, and c N/P ratio. Mixed litter is represented by diamonds with blue lines, and Eucalyptus spp. is represented by red squares with dotted lines

more efficient at decomposing and cycling nutrients than the material composed only of Eucalyptus leaves, which might drive the restoration process in some urban areas.

The mixed composition of litter was also more efficient in nitrogen retranslocation than were the Eucalyptus leaves, demonstrating a greater efficiency of these species in translocating nitrogen prior to leaf abscission, which generates less dependence on the nitrogen absorbed by plant roots. Finzi et al. (2001) showed similar nitrogen retranslocation values for Betula ermanii (34\%), but higher values for Sasa kurilensis (51\%). This value was not higher in Eucalyptus leaves, given that the strategy is expected to be more efficient in fastergrowing exotic species.

The abundant presence of macro- and micronutrients in tree leaves forming MLF shows a particularity which is very favorable for the establishment of tree species in the soils of tropical areas (Gama-Rodrigues et al. 2003). Even though MLF composition is not formed exclusively by the leaves of native species, the strategy of mixing native and exotic species has been widely used in reforestation programs, since some non-native trees have a high potential for decorating public spaces. An example of this use of exotic species can be found in the

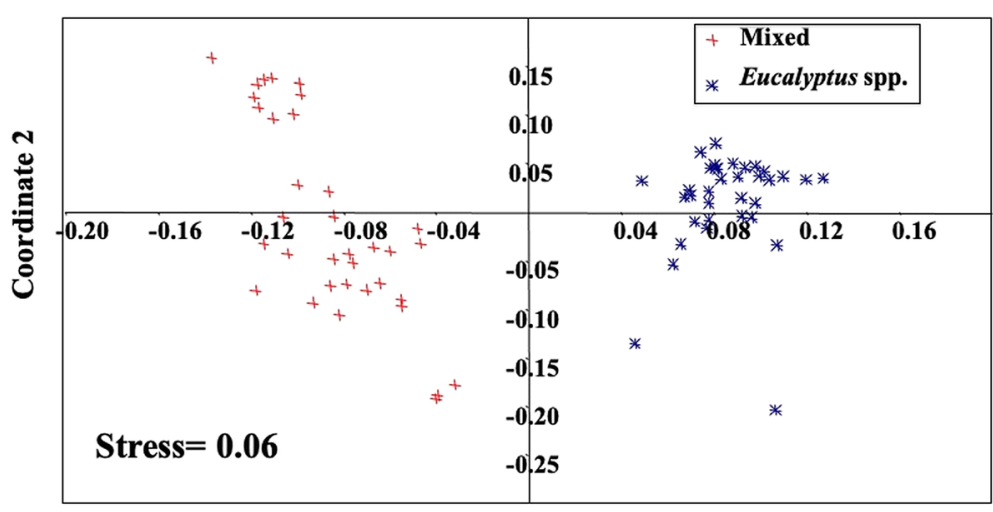

\section{Coordinate 1}

Fig. 6 Non-metric multidimensional scaling (NMDS) diagram plotting the order of macro- and micronutrients and litter origin. The stress value is the distortion between the original data and data plotted in the diagram. Statistical inference of dissimilarity between the groups was obtained by one-way analysis of similarities (ANOSIM) considering a $p$-value $\leq 0.05$ 
Table 6 Main effects of origin, time, and the interaction between both (origin $\times$ time) on macro- and micronutrients obtained by multivariate analysis of variance (MANOVA)

\begin{tabular}{llllll}
\hline Effect & Wilks $\boldsymbol{\lambda}$ value & Degree of freedom (DF) & DF error & $\boldsymbol{p}$ value & $\boldsymbol{\eta}^{\mathbf{2}}$ partial \\
\hline Interception & 1.000 & 11 & 50.000 & 1.000 & $>0.001$ \\
Origin & 0.021 & 11 & 50.000 & $>0.001$ & 0.979 \\
Time & 0.679 & 44 & 193.242 & 0.998 & 0.092 \\
Origin $\times$ time & 0.675 & 44 & 193.242 & 0.998 & 0.094 \\
\hline
\end{tabular}

Significance occurs at the 0.05 level

recently updated Reforestation Manual of São Paulo City (São Paulo 2016).

The discrepancy in nutritional content reported between the canopy leaves of EU and those forming MLF can be attributed to an intrinsic characteristic of each species, even though the initial Mn content in Eucalyptus spp. litter was almost twice that of MLF (Magalhães and Blum 1999; Gama-Rodrigues et al. 2003). Aside from the amount of nutrients in the leaves, some elements are scarce in nature but still very important for vegetal metabolism. Thus, plants translocate some elements through the phloem, optimizing their reutilization for metabolic activities (Xu et al. 2012). Some authors have shown that the nutritional scarcity in soil makes plants more efficient in nutrient translocation, thus interfering with soil fertility maintenance in tropical forests (Silva et al. 1998; Nunes et al. 2014). This was the case for some nutrients that exhibited values in recently fallen leaf material that were much smaller than the values observed in canopy leaves.

Macronutrients, including $\mathrm{N}, \mathrm{P}$, and $\mathrm{K}$, are important for building biological tissue and maintaining metabolic processes. As such, they are fundamental elements for biodiversity maintenance (Vitousek 1984). The loss of these elements during the first 30 days of the study demonstrates the efficiency of decomposing organisms before the elements are eventually leached from the system (Boeger and Wisniewski 2003). MLF potassium revealed a more evident decomposition in time than did EU potassium. These results reinforce the concept that initial concentrations of $\mathrm{N}, \mathrm{P}$, and $\mathrm{K}$ have major influences on mass loss (Yang et al. 2004; Tateno et al. 2007).

The loss of N, P, and $\mathrm{K}$ reported in this study is in agreement with the results of Parrota (1999) and Wang et al. (2008), who found a greater loss of these elements in MLF compositions than in the litter composition of only one species, even though these studies were not specifically focused on the use of exotic or alien species. In studying MLF compositions, Wang et al. (2008) found that the rapid decomposition of deciduous material accelerates nutrient return to the soil, thus facilitating tree growth and the increase of litterfall production.

The Ca decomposition curve over time was higher for MLF than for EU litter. This could be attributed to the high $\mathrm{Ca}$ content contained in litter composition as well as the multiple benefits that elements provide to the microbial community in the soil. Specifically, $\mathrm{Ca}$ promotes the reduction of acidity in the edaphic system, increases microbial activity, decreases aluminum toxicity, and indirectly benefits root development. Asner and Martin (2015) reported a relationship between soil fertility and the presence of both $\mathrm{P}$ and $\mathrm{Ca}$ in the tree leaves of a tropical region. Although a phylogenetic signal in nutritional content is found in the tree leaves of tropical regions, this finding suggests that the amount of $\mathrm{P}$ and $\mathrm{Ca}$ in leaves can be strongly influenced by the conditions of the study site.

Sulfur (S) in MLF decreased more than in EU litter over time. This element is known to play an important role in maintaining bacterial populations, since the oxidation of sulfates present in the soil is strongly associated with the presence of autotrophic aerobic bacteria (Kennedy 1999), thereby strengthening the food chain in the edaphic system.

It was observed that zinc, a micronutrient, declined constantly throughout the experimental period in the material formed by Eucalyptus leaves. A different behavior was observed in MLF over time. According to Martins (2009), soil pH can interfere with the availability of $\mathrm{Zn}$ for plants and other decomposing organisms.

The micronutrients boron and manganese showed stability over time in Eucalyptus spp. litter, unlike the mixed species that showed significant decomposition. Manganese plays a crucial role in photosynthesis, and its release and consequent reabsorption are very important to protect new leaves against fungi and to participate in energy metabolism (Malavolta et al. 1997). In the present study, the mixed composition of litter presented a higher contribution of $\mathrm{Mn}$ return, demonstrating the potential for quickly aiding forest productivity. The iron decomposition curve in this study showed strong data variability around the average, making it difficult to visualize any trend over time. The return of copper to the soil presented a similar curve between MLF and EU composition; however, mixed species presented a greater amount of this content during all analyzed periods. Mateus et al. (2008) reported an association between $\mathrm{Cu}$ 
and soil organic matter, which contributes to its rapid absorption by the edaphic system.

The study showed that MLF was more efficient in losing mass and returning nutrients to soil than EU. This finding reinforces the use of a mixed species approach in restoration programs of urban areas instead of a single species approach, as was done in some São Paulo reforestation programs.

The efficiency of nitrogen use is often characterized by high values of the C:N ratio (Vitousek 1984; Luca et al. 2018). The present study identified an increase in this ratio over time noting that, proportionally, $\mathrm{N}$ was preferably consumed by decomposers in relation to $\mathrm{C}$ (Fernandes et al. 2006; Tripathi et al. 2006). One important factor that could interfere with this relationship is the abundance of Leguminosae, which might alter the availability of $\mathrm{N}$ in the soil (Siddique et al. 2008). Pinto et al. (2016) also found higher values of $\mathrm{C}$ and $\mathrm{N}$ in Eucalyptus litter in relation to native forest leaves in Bahia, Northeastern Brazil. The authors related the lower C:N ratio in native leaves to the quality of the material and thus the preference for decomposition by microbial diversity. The C:P ratio followed a trend similar to that of nitrogen; however, the same increase was not noticed after 150 days of material exposure, as shown in the C:N ratio. In EU litter, the N:P ratio revealed that nitrogen loss was higher than phosphorus loss over time, highlighting the decomposition rate in time and increased nitrogen consumption in relation to phosphorus.

Multivariate analyses (NMDS and MANOVA) clearly pointed out that litter nutrient loss to the soil is distinct between MLF and EU. Such evidence further reinforces the efficiency of mixed composition in nutrient cycling in the urban forest of São Paulo. It also emphasizes that having used Eucalyptus spp. in the green area reforestation programs of São Paulo over the last century can impact ecosystems in city forests.

The results presented herein clearly shed light on the ecological implications of São Paulo's reforestation programs in the last century, which have basically appropriated Eucalyptus as a species to recompose urban green areas. However, a larger number of species must be tested to obtain greater clarity on nutrient cycling in urban forest fragments (Sanesi et al. 2017; Tomao et al. 2017).

\section{Conclusions}

Litter formed by mixed species shows a higher decomposition rate in relation to that formed only by the leaves of Eucalyptus spp. This was demonstrated by major mass losses and nutrient return to the soil. In general, nutrients were found in higher amounts in MLF and yielded higher soil return values compared to EU material; the same trend was observed for micronutrients. The C:N and C:P ratios exhibited an efficient devolution of these elements to the edaphic system, highlighting their importance in the decomposing community.

The significant difference in nutrient return, as shown by NMDS and MANOVA, reinforces the concept that in urban reforestation programs the City of São Paulo must consider the environmental and biogeographic characteristics of the species employed. Relevant attributes of city treescapes such as highshade capacity and relatively fast growth are important, but soil nutrient return must also be accounted for so that vegetation can contribute to higher soil fertility and better conditions for urban forest productivity (Mattijssen et al. 2017; Chen et al. 2016).

\section{Abbreviations}

MASP: Metropolitan area of São Paulo; EU: Leaves of Eucalyptus spp.; MLF: Leaves from two native and two exotic species; NMDS: Non-metric multidimensional scaling; ANOSIM: One-way analysis of similarities; MANOVA: Multivariate analysis of variance; N: Nitrogen; P: Phosphorus; C: Carbon; K: Potassium; Ca: Calcium; Mg: Magnesium; S: Sulfur; B: Boron; Zn: Zinc; Mn: Manganese; Fe: Iron; Cu: Copper; pH: Hydrogen potential; H + Al: Hydrogen + aluminum; SB: Sum of bases; SOM: Soil organic matter; V: Base saturation

\section{Acknowledgements}

We thank the editor and two anonymous reviewers for their comments and suggestions.

\section{Authors' contributions}

All authors have collaborated in an equal manner in designing the work, collecting and analyzing data, or writing the manuscript. All authors have read and approved the final manuscript.

\section{Funding}

This work was supported by the São Paulo Research Foundation (FAPESP), project number 2019/24325-2.

\section{Availability of data and materials}

All data generated or analyzed during this study are included in this published article.

\section{Declarations}

Ethics approval and consent to participate

Not applicable.

\section{Consent for publication}

Not applicable.

\section{Competing interests}

The authors declare they have no competing interests.

\section{Author details}

${ }^{1}$ Master's Program in Health Promotion, Adventist University of São Paulo, São Paulo, SP, Brazil. 'Master's Program in Geoenvironmental Analysis, University of Guarulhos, Guarulhos, SP, Brazil. ${ }^{3}$ Department of Health, Faculty of Biological Science, University Nove de Julho (UNINOVE), São Paulo, SP, Brazil. ${ }^{4}$ Institute of Botany (IBT/SP), São Paulo, SP, Brazil. ${ }^{5}$ Department of Civil Engineering, São Judas Tadeu University, São Paulo, SP, Brazil. ${ }^{6}$ Institute of Forestry (IF/SP), São Paulo, SP, Brazil. ${ }^{7}$ Centro de Energia Nuclear na Agricultura (CENA/USP), University of São Paulo, Piracicaba, SP, Brazil. ${ }^{8}$ Prefeitura da cidade de São Paulo (Secretaria do Verde e Meio Ambiente), São Paulo, SP, Brazil. ${ }^{9}$ Department of Agricultural and Environmental Sciences, University of Bari Aldo Moro, Bari, Italy. ${ }^{10}$ Department of Geography, The University of Hong Kong, Centennial Campus, Pokfulam Road, Hong Kong, Hong Kong. 


\section{Received: 7 October 2020 Accepted: 8 March 2021} Published online: 01 May 2021

\section{References}

Adams LW (2005) Urban wildlife ecology and conservation: a brief history of the discipline. Urban Ecosyst 8(2):139-156. https://doi.org/10.1007/s11252-005-43 77-7

Arratia ALD, Ribeiro AP, Quaresma CC, Rodrigues EA, Lucca EFD, Camargo PBD, Nascimento APB, Ferreira ML (2020) Structure and biomass analysis of urban vegetation in squares of Santa Cecília district, São Paulo, SP. Revista Árvore 44:e4417. https://doi.org/10.1590/1806-908820200000017

Asner GP, Martin RE (2015) Convergent elevation trends in canopy chemical traits of tropical forests. Global Change Biol 22(6):2216-2227. https://doi.org/1 $0.1111 /$ gcb.13164

Bachega LR, Bouillet JP, Cássia Piccolo M, Saint-André L, Bouvet JM, Nouvellon Y, Laclau JP (2016) Decomposition of Eucalyptus grandis and Acacia mangium leaves and fine roots in tropical conditions did not meet the Home Field Advantage hypothesis. Forest Ecol Manag 359:33-43. https://doi.org/10.1016/ j.foreco.2015.09.026

Bala N, Pramod K, Bohra NK, Limba NK, Baloch SR, Singh G (2010) Production and decomposition of litter in plantation forests of Eucalyptus camaldulensis along canal command area in Indian desert. Indian Forester 136(2):163-172

Barlow J, Gardner TA, Ferreira LV, Peres CA (2007) Litter fall and decomposition in primary, secondary and plantation forests in the Brazilian Amazon. Forest Ecol Manag 247(1-3):91-97. https://doi.org/10.1016/j.foreco.2007.04.017

Benchimol JF, Nascimento Lamano-Ferreira AP, Ferreira ML, Cortese TTP, Ramos HR (2017) Decentralized management of public squares in the city of São Paulo, Brazil: implications for urban green spaces. Land use Policy 63:418427. https://doi.org/10.1016/j.landusepol.2017.02.004

Boeger MRT, Wisniewski C (2003) Comparação da morfologia foliar de espécies arbóreas de três estádios sucessionais distintos de floresta ombrófila densa (Floresta Atlântica) no Sul do Brasil. Revista Brasileira de Botânica 26:61-72

Botelho JDM, Lamano-Ferreira APDN, Ferreira ML (2014) Prática de cultivo e uso de plantas domésticas em diferentes cidades brasileiras. Ciência Rural 44(10): 1810-1815. https://doi.org/10.1590/0103-8478cr20131036

Bulbovas P, Camargo CZ, Ferreira ML, Domingos M (2020) Anthropic interferences in the nutritional status of tree species growing in urban and peri-urban Atlantic forest remnants. Urban For Urban Green 50:126642. https://doi.org/10.1016/j.ufug.2020.126642

Chen J, Zhu L, Fan P, Tian L, Lafortezza R (2016) Do green spaces affect the spatiotemporal changes of $\mathrm{PM}_{2.5}$ in Nanjing? Ecol Process 5:7

Chen WY, Hua J (2015) Citizens' distrust of government and their protest responses in a contingent valuation study of urban heritage trees in Guangzhou, China. J Environ Manage 155:40-48. https://doi.org/10.1016/j. jenvman.2015.03.002

Cianciaruso MV, Pires JSR, Delitti WBC, Silva ÉFLPD (2006) Litter fall and leaf decomposition in cerradão Jataí Reserve, municipality of Luiz Antônio, São Paulo State, Brazil. Acta Botanica Brasilica, 20(1):49-59.

Cizungu L, Staelens J, Huygens D, Walangululu J, Muhindo D, Van Cleemput O, Boeckx P (2014) Litterfall and leaf litter decomposition in a central African tropical mountain forest and Eucalyptus plantation. Forest Ecol Manag 326: 109-116. https://doi.org/10.1016/j.foreco.2014.04.015

Climate-Data.Org - Clima Sapopemba. http://pt.climate-data.org/location/286822/. Accessed 31 May 2015

Costa GS, Gama-Rodrigues ACD, Cunha GDM (2005) Decomposição e liberação de nutrientes da serapilheira foliar em povoamentos de Eucalyptus grandis no norte fluminense. Revista Árvore 29(4):563-570. https://doi.org/10.1590/ S0100-67622005000400008

Demessie A, Singh BR, Lal R, Strand LT (2012) Leaf litter fall and litter decomposition under Eucalyptus and coniferous plantations in Gambo District, southern Ethiopia. Acta Agric Scand Section B-Soil Plant Sci 62(5): 467-476

Enloe HA, Lockaby BG, Zipperer WC, Somers GL (2015) Urbanization effects on leaf litter decomposition, foliar nutrient dynamics and aboveground net primary productivity in the subtropics. Urban Ecosyst 18(4):1285-1303. https://doi.org/10.1007/s11252-015-0444-x

Fernandes MM, Pereira MG, Magalhães LMS, Cruz AR, Giácomo RG (2006) Aporte e decomposição de serapilheira em áreas de floresta secundária, plantio de sabiá (Mimosa caesalpiniaefolia Benth.) e andiroba (Carapa guianensis Aubl.) na Flona Mário Xavier, RJ. Ciência Florestal 16(2):163-175. https://doi.org/10. 5902/198050981897
Ferreira ML, Andrade NGV, Costa MCLD, Araujo DM, Côrtes PL, Quaresma CC, Conti DM, Camargo PB (2019) Soil fertility and litterfall assessment in a periurban forest of São Paulo, SP: understanding for urban green areas management. HOLOS 3:1-16. https://doi.org/10.15628/holos.2019.8290

Ferreira ML, Esposito JBN, de Souza SR, Domingos M (2012) Critical analysis of the potential of Ipomoea nil 'Scarlet O'Hara'for ozone biomonitoring in the sub-tropics. J Environ Monit 14(7):1959-1967. https://doi.org/10.1039/c2em3 0026e

Ferreira ML, Pereira EE, Monteiro P (2014a) Ciclagem de nutrientes numa floresta urbana no município de São Paulo, SP. Periódico Técnico e Científico Cidades Verdes 2(2):1-17

Ferreira ML, Ribeiro AP, Albuquerque CR, Ferreira APDNL, Figueira RCL, Lafortezza $R$ (2017) Air contaminants and litter fall decomposition in urban forest areas: the case of São Paulo-SP, Brazil. Environ Res 155:314-320. https://doi.org/10.1 016/j.envres.2017.02.023

Ferreira ML, Silva JL, Pereira EE, Lamano-Ferreira APBN (2014b) Litter fall production and decomposition in a fragment of secondary Atlantic Forest of São Paulo, SP, southeastern Brazil. Revista Árvore 38(4):591-600. https://doi. org/10.1590/S0100-67622014000400002

Ferreira ML, Souza LC, Conti DDM, Quaresma CC, Tavares AR, Silva KG, Camargo PB (2018) Soil biodiversity in urban forests as a consequence of litterfall management: implications for São Paulo's ecosystem services. Sustainability 10(3):684. https://doi.org/10.3390/su10030684

Ferreira ML, Uchiyama EA (2015) Litterfall assessment in a fragment of secondary tropical forest, Ibiúna, SP, Southeastern Brazil. Revista Árvore 39(5):791-799. https://doi.org/10.1590/0100-67622015000500002

Ferreira V, Elosegi A, Gulis V, Pozo J, Graça MA (2006) Eucalyptus plantations affect fungal communities associated with leaf-litter decomposition in Iberian streams. Archiv für Hydrobiologie 166(4):467-490. https://doi.org/10.1127/ 0003-9136/2006/0166-0467

Finzi AC, Allen AS, Lucia EH, Ellsworth DS, Schlesinger WH (2001) Forest litter production, chemistry, and decomposition following two years of free-air $\mathrm{CO}_{2}$ enrichment. Ecology 82:470-484

Gama-Rodrigues AC, Barros NF, Santos ML (2003) Decomposição e liberação de nutrientes do folhedo de espécies florestais nativas em plantios puros e mistos no sudeste da Bahia. Revista Brasileira de Ciências do Solo 27(6):10211031. https://doi.org/10.1590/S0100-06832003000600006

Gatto A, Bussinguer AP, Ribeiro FC, Azevedo GB, Bueno MC, Monteiro MM, de Souza PF (2014) Ciclagem e balanço de nutrientes no sistema solo-planta em um plantio de Eucalyptus sp., no Distrito Federal. Revista Brasileira de Ciências do Solo 38(3):879-887. https://doi.org/10.1590/S0100-068320140003 00019

Giweta M (2020) Role of litter production and its decomposition, and factors affecting the processes in a tropical forest ecosystem: a review. J Ecol Environ 44:1-9

Guo LB, Sims REH (1999) Litter decomposition and nutrient release via litter decomposition in New Zealand eucalypt short rotation forests. Agric Ecosyst Environ 75(1-2):133-140. https://doi.org/10.1016/S0167-8809(99)00069-9

Hoppen MI, Divensi HF, Ribeiro RF, Caxambú MG (2015) Espécies exóticas na arborização de vias públicas no município de Farol, PR, Brasil. Revista da Sociedade Brasileira de Arborização Urbana 9(3):173-186. https://doi.org/10. 5380/revsbau.v9i3.63166

IAG/USP (2015) Instituto de Astronomia, Geofísica e Ciências Atmosféricas da USP Arquivo/Boletins Climatológicos. http://estacao.iag.usp.br/boletim.php. Accessed 23 November 2015.

IBGE (2020) Panorama de Cidades. https://cidades.ibge.gov.br/brasil/sp/sao-paulo/ panorama. Accessed 28 September 2020

Jesus PR, Filho HOL, Ferreira ML (2014) Litterfall production in three different sites with different abundance of eucalyptus (Eucalyptus spp.) at the Piqueri Park, SP. Brazilian J Ecol 1-2:59-65

Kennedy AC (1999) Bacterial diversity in agroecosystems. Agric Ecosyst Environ 74(1-3):65-76. https://doi.org/10.1016/S0167-8809(99)00030-4

Kumar BM (2008) Litter dynamics in plantation and agroforestry systems of the tropics - a review of observations and methods. Ecological Basis of Agroforestry. Boca Raton: CRC Press, USA

Lafortezza R, Chen J (2016) The provision of ecosystem services in response to global change: evidences and applications. Environ Res 147:576-579. https:// doi.org/10.1016/j.envres.2016.02.018

Lewis SL, Lopez-Gonzalez G, Sonké B, Affum-Baffoe K, Baker TR, Ojo LO, Phillips OL, Reitsma JM, White L, Comiskey JA, Djuikouo MNK, Ewango CEN, Feldpausch TR, Hamilton AC, Gloor M, Hart T, Hladik A, Lloyd J, Lovett JC, 
Makana JR, Malhi Y, Mbago FM, Ndangalasi HJ, Peacock J, Peh KSH, Sheil D, Sunderland T, Swaine MD, Taplin J, Taylor D, Thomas SC, Votere R, Wöll H (2009) Increasing carbon storage in intact African tropical forests. Nature 457(7232):1003-1006. https://doi.org/10.1038/nature07771

Lima GN, Rueda VOM (2018) The urban growth of the metropolitan area of Sao Paulo and its impact on the climate. Weather Climate Extremes 21:17-26. https://doi.org/10.1016/j.wace.2018.05.002

Lôbo D, Leão T, Melo FP, Santos AM, Tabarelli M (2011) Forest fragmentation drives Atlantic forest of northeastern Brazil to biotic homogenization. Divers Distrib 17(2):287-296. https://doi.org/10.1111/j.1472-4642.2010.00739.x

Louzada JN, Schoereder J, De Marco Jr P (1997) Litter decomposition in semideciduous forest and Eucalyptus spp. crop in Brazil: a comparison. Forest Ecol Manag 94(1-3):31-36. https://doi.org/10.1016/S0378-1127(96)03986-2

Luca EF, Chaplot V, Mutema M, Feller C, Ferreira ML, Cerri CC, Couto HTZ (2018) Effect of conversion from sugarcane preharvest burning to residues greentrashing on SOC stocks and soil fertility status: results from different soil conditions in Brazil. Geoderma 310:238-248. https://doi.org/10.1016/j. geoderma.2017.09.020

Magalhães LMS, Blum WEH (1999) Concentração e distribuição de nutrientes nas folhas de espécies florestais, na Amazônia Ocidental. Floresta e Ambiente 6: 127-137

Malavolta E, Vitti GC, Oliveira SA (1997) Avaliação do estado nutricional das plantas: princípios e aplicaçōes. Facultad de Agronomia. 2. ed. Potafos, Piracicaba, São Paulo. 319.

Martinelli LA, Lins SR, Santos-Silva JC (2017) Fine litterfall in the Brazilian Atlantic forest. Biotropica 49(4):443-451. https://doi.org/10.1111/btp.12448

Martins APL, Reissmann CB (2007) Material vegetal e as rotinas laboratoriais nos procedimentos químico-analíticos. Scientia Agraria 8(1):1-17. https://doi.org/1 0.5380/rsa.v8i1.8336

Martins C, Natal-da-Luz T, Sousa JP, Goncalves MJ, Salgueiro L, Canhoto C (2013) Effects of essential oils from Eucalyptus globulus leaves on soil organisms involved in leaf degradation. PLoS One 8(4):e61233. https://doi.org/10.1371/ journal.pone.0061233

Martins RAC (2009) Efeito de adjuvantes sobre absorção de zinco e manganês na adubação foliar. Doctorate thesis. Universidade Federal de Goiás. 2009.

Mateus GP, Crusciol CAC, Borghi É (2008) Efeito da palhada do sorgo de guiné "gigante" na nutrição foliar e produtividade da soja em plantio direto. Acta Sci-Agron 29:497-502. https://doi.org/10.4025/actasciagron.v29i4.411

Mattijssen TJM, van der Jagt APN, Buijs AE et al (2017) The long-term prospects of citizens managing urban green space: from place making to placekeeping? Urban Forestry Urban Greening 26:78-84. https://doi.org/10.1016/j. ufug.2017.05.015

MDA - Ministério do Desenvolvimento Agrário - INSTRUÇÃO NORMATIVA № 2 , DE 9 de outubro de 2008. http://www.mda.gov.br/sitemda/sites/sitemda/ files/user_arquivos_627/Aba\%2010\%20-\%20Anexo\%2001\%20-\%20Instru\% C3\%A7\%C3\%A30\%20Normativa\%20MAPA.pdf. Accessed in 24 nov 2015.

Moraes RM, Delitti WBC, Struffaldi-de Vuono Y (1999) Litterfall and litter nutrient content in two Brazilian Tropical Forests. Revista Brasileira de Botânica 22:9-16

Nakazato RK, Lourenço IS, Esposito MP, Lima ME, Ferreira ML, Campos ROA, Rinaldi M, Domingos M (2020) Trace metals at the tree-litter-soil-interface in Brazilian Atlantic Forest plots surrounded by sources of air pollution. Environ Pollut 268:115797

Nunes EN, Fernandes YTD, de Araújo Montenegro IN, Alves CAB, Souto JS (2014) Eficiência da translocação de nutrientes em plantas. Revista Verde de Agroecologia e Desenvolvimento Sustentável 8:90-95

Parrota JA (1999) Productivity, nutrient cycling, and succession in single- and mixed-species plantations of Casuarina equisetifolia, Eucalyptus robusta, and Leucaena leucocephala in Puerto Rico. Forest Ecol Manag 124(1):45-77. https://doi.org/10.1016/S0378-1127(99)00049-3

São Paulo (2016) Manual Técnico de Arborização Urbana. Prefeitura da cidade de São Paulo. https:/www.sosma.org.br/wp-content/uploads/2015/03/MANUA L-ARBORIZACAO_22-01-15_.pdf. Accessed 25 October 2016.

Pedroso ANV, Bussotti F, Papini A, Tani C, Domingos M (2016) Pollution emissions from a petrochemical complex and other environmental stressors induce structural and ultrastructural damage in leaves of a biosensor tree species from the Atlantic Rain Forest. Ecol Indic 67:215-226. https://doi.org/10.1016/j. ecolind.2016.02.054

Pinto HCA, Barreto PAB, Gama-Rodrigues EF, Oliveira FGRB, Paula A, Amaral AR (2016) Decomposição da serapilheira foliar de floresta nativa e plantios de Pterogyne nitens e Eucalyptus urophylla no sudoeste da Bahia. Ciência Florestal 26(4):1141-1153. https://doi.org/10.5902/1980509825105
Pozo J, Basaguren A, Elosegui A, Molinero J, Fabre E, Chauvet E (1998) Afforestation with Eucalyptus globulus and leaf litter decomposition in streams of northern Spain. Hydrobiologia 374:101-109

Qian S, Qi M, Huang L, Zhao L, Lin D, Yang Y (2016) Biotic homogenization of China's urban greening: a meta-analysis on woody species. Urban For Urban Green 18:25-33. https://doi.org/10.1016/j.ufug.2016.05.002

Saatchi SS, Harris NL, Brown S, Lefsky M, Mitchard ETA, Salas W, Zutta BR, Buermann W, Lewis SL, Hagen S, Petrova S, White L, Silman M, Morel A (2011) Benchmark map of forest carbon stocks in tropical regions across three continents. Proc. Natl. Acad. Sci. USA 108(24):9899-9904. https://doi. org/10.1073/pnas.1019576108

Sampaio AB, Schmidt IB (2014) Espécies exóticas invasoras em unidades de conservação federais do Brasil. Biodiversidade Brasileira 2:32-49

Sanesi G, Lafortezza R, Marziliano PA, Ragazzi A, Mariani L (2017) Assessing the current status of urban forest resources in the context of Parco Nord, Milan, Italy. Landscape Ecol Eng 3(2):187-198

Scheer MB (2008) Decomposição e liberação de nutrientes da serapilheira foliar em um trecho de floresta ombrófila densa aluvial em regeneração, Guaraqueçaba (PR). Floresta 38:253-266

Shams ZI (2016) Changes in diversity and composition of flora along a corridor of different land uses in Karachi over 20 years: causes and implications. Urban For Urban Green 17:71-79. https://doi.org/10.1016/j.ufug.2016.03.002

Shanks R, Olson JS (1961) First year breakdown of leaf litter in Southern Appalachia Forest. Science 134:194-195

Siddique I, Engel VL, Parrota J, Lamb D, Nardoto GB, Ometto JPHB, Martinelli LA, Schmidth S (2008) Dominance of legume trees alters nutrient relations in mixed species forest restoration plantings within seven years. Biogeochemistry 88(1):89-101. https://doi.org/10.1007/s10533-008-9196-5

Silva AC, dos Santos AR, Paiva AV (1998) Translocação de nutrientes em folhas de Hevea brasiliensis (clone) e em acículas de Pinus oocarpa. Revista da Universidade de Alfenas 4:11-18

Silva PHM, Bouillet JP, Paula RC (2016) Assessing the invasive potential of commercial Eucalyptus species in Brazil: Germination and early establishment. Forest Ecol Manag 374:129-135. https://doi.org/10.1016/j.foreco.2016.05.007

Silva-Junior EF, Moulton TP, Boechat IG, Gucker B (2014) Leaf decomposition and ecosystem metabolism as functional indicators of land use impacts on tropical streams. Ecol Indic 36:195-204. https://doi.org/10.1016/j.ecolind.2013.07.027

Sousa-Neto ER, Lins SRM, Martins SC, Cássia Piccolo M, Ferreira ML, Camargo PB, Martinelli LA (2017) Litterfall mass and nutrient fluxes over an altitudinal gradient in the coastal Atlantic Forest, Brazil. J Trop Ecol 33(4):261-269. https://doi.org/10.1017/S0266467417000207

Stromberg JC, Makings E, Eyden A, Madera R, Samsky J, Coburn FS, Scott BD (2016) Provincial and cosmopolitan: floristic composition of a dryland urban river. Urban Ecosyst 19(1):429-453. https://doi.org/10.1007/s11252-015-0482-4

Suominien $L$ (2013) Predicting soil properties from floristic composition in western Amazonian rain forests: performance of $k$-nearest neighbour estimation and weighted averaging calibration. J Appl Ecol 50(6):1441-1449. https://doi.org/10.1111/1365-2664.12131

Tateno R, Tokuchi N, Yamanaka N, Du S, Otsuki K, Shimamura T, Xue Z, Wang S, Hou Q (2007) Comparison of litterfall production and leaf litter decomposition between an exotic black locust plantation and an indigenous oak forest near Yan'an on the Loess Plateau, China. Forest Ecol Manag 241(13):84-90. https://doi.org/10.1016/j.foreco.2006.12.026

Thomas RJ, Asakawa NM (1993) Decomposition of leaf litter from tropical forage grasses and legumes. Soil Biol Biogeochem 25(10):1351-1361. https://doi. org/10.1016/0038-0717(93)90050-L

Tomao A, Quatrini V, Corona P et al (2017) Resilient landscapes in Mediterranean urban areas: understanding factors influencing forest trends. Environ Res 156: 1-9. https://doi.org/10.1016/j.envres.2017.03.006

Tripathi SK, Sumida A, Shibata H, Ono K, Uemura S, Kodama Y, Hara T (2006) Leaf litterfall and decomposition of different above- and belowground parts of birch (Betula ermanii) trees and dwarf bamboo (Sasa kurilensis) shrubs in a young secondary forest in Northern Japan. Biol Fertil Soils 43(2):237-246. https://doi.org/10.1007/s00374-006-0100-y

Valente FDV, Neves LG, Tienne L, Marques O, Cortines E, Valcarcel R (2005) Produção e decomposição de serrapilheira em medidas biológicas de reabilitação de áreas de empréstimo na Mata Atlântica. Revista Universidade Rural 25:18-25

Vitousek PM (1984) Litter fall, nutrient cycling, and nutrient limitation in tropical forests. Ecology 65(1):285-298. https://doi.org/10.2307/1939481 
Wang Q, Wang S, Huang Y (2008) Comparisons of litterfall, litter decomposition and nutrient return in a monoculture Cunninghamia lanceolata and a mixed stand in southern China. Forest Ecol Manag 255(3-4):1210-1218. https://doi. org/10.1016/.joreco.2007.10.026

Xu G, Fan X, Miller AJ (2012) Plant nitrogen assimilation and use efficiency. Ann Rev Plant Biol 63(1):153-182. https://doi.org/10.1146/annurev-arplant-042 811-105532

Yang YS, Chen YX, He ZM, Guo JF (2004) Comparatively study on litter properties between plantations of Fokienia hodginsii and Cunninghamia lanceolata. Sci Silvae $\operatorname{Sin}$ 40:2-9

Yitaferu B, Abewa A, Amare T (2013) Expansion of Eucalyptus woodlots in the fertile soils of the highlands of Ethiopia: could it be a treat on future cropland use? J Agric Sci 5:97-107

\section{Publisher's Note}

Springer Nature remains neutral with regard to jurisdictional claims in published maps and institutional affiliations.

\section{Submit your manuscript to a SpringerOpen ${ }^{\circ}$ journal and benefit from:}

- Convenient online submission

- Rigorous peer review

- Open access: articles freely available online

- High visibility within the field

- Retaining the copyright to your article

Submit your next manuscript at $\boldsymbol{\nabla}$ springeropen.com 